\title{
Pulmonary Complications of Malignancies and Blood and Marrow Transplantation
}

\author{
Geshani Jayasuriya, Beryl Lin, Steven J. Keogh, and Hiran Selvadurai
}

\section{Abbreviations}

$\begin{array}{ll}\text { AIP } & \text { Acute interstitial pneumonitis } \\ \text { ALL } & \text { Acute lymphoblastic anaemia } \\ \text { AML } & \text { Acute myeloid leukaemia } \\ \text { APL } & \text { Acute promyelocytic leukaemia } \\ \text { ARDS } & \text { Acute respiratory distress syndrome } \\ \text { BMT } & \text { Bone marrow transplantation } \\ \text { BOOP } & \text { Bronchiolitis obliterans with organising pneumonia } \\ \text { BOS } & \text { Bronchiolitis obliterans syndrome } \\ \text { CBO } & \text { Constrictive bronchiolitis obliterans } \\ \text { cGVHD } & \text { Chronic graft-versus-host disease }\end{array}$

G. Jayasuriya, B.Med., F.R.A.C.P. • H. Selvadurai, M.B.B.S., F.R.A.C.P., Ph.D. ( $ه)$ Department of Respiratory Medicine, The Children's Hospital, Sydney, NSW, Australia

Discipline of Child and Adolescent Health, The University of Sydney,

Camperdown, NSW, Australia

e-mail: geshani.jayasuriya@health.nsw.gov.au; hiran.selvadurai@health.nsw.gov.au

B. Lin

The University of New South Wales, Sydney, NSW, Australia

S.J. Keogh, M.B.B.S.Hons., F.R.A.C.P.

Discipline of Child and Adolescent Health, The University of Sydney,

Camperdown, NSW, Australia

Department of Oncology, The Children's Hospital, Sydney, NSW, Australia

e-mail: steven.keogh@health.nsw.gov.au 


$\begin{array}{ll}\text { CMV } & \text { Cytomegalovirus } \\ \text { COP } & \text { Cryptogenic organising pneumonia } \\ \text { DAH } & \text { Diffuse alveolar haemorrhage } \\ \text { DL }_{\text {CO }} & \text { Diffusing capacity for carbon monoxide } \\ \text { EBV } & \text { Epstein-Barr virus } \\ \text { GVHD } & \text { Graft-versus-host disease } \\ \text { HL } & \text { Hodgkin lymphoma } \\ \text { IPS } & \text { Idiopathic pneumonia syndrome } \\ \text { LCH } & \text { Langerhans cell histiocytosis } \\ \text { MPS } & \text { Mucopolysaccharidosis } \\ \text { NCPE } & \text { Non-cardiogenic pulmonary oedema } \\ \text { PAH } & \text { Pulmonary arterial hypertension } \\ \text { PAWP } & \text { Pulmonary artery wedge pressure } \\ \text { PERDS } & \text { Peri-engraftment respiratory distress syndrome } \\ \text { PH } & \text { Pulmonary hypertension } \\ \text { PTLD } & \text { Post-transplant lymphoproliferative disease } \\ \text { PVOD } & \text { Pulmonary veno-occlusive disease } \\ \text { SVC } & \text { Superior vena cava }\end{array}$

\section{Introduction}

Despite improvements in survival among cancer patients and BMT recipients there is still substantial morbidity and mortality) associated with pulmonary complications [1-9]. Pulmonary injury can be complex and multifactorial and thus will be examined in relation to underlying malignancy, infectious and non-infectious etiologies as summarised in Table 1. Toxicity resulting from radiation therapy is described in chapter "Pulmonary Complications of Radiation Therapy".

Table 1 Classification of common complications of childhood cancer affecting the chest [1-3]

\begin{tabular}{l|l|l}
\hline Malignancy & Infections & Non-infectious and immune \\
\hline Primary and metastatic tumours & Impaired immune & Drug or radiation toxicity \\
Pulmonary infiltrate from systemic & function & - Acute hypersensitivity \\
disease & Bacterial & reactions \\
Leukemic and lymphomatous & Viral & - Interstitial pneumonitis \\
involvement & Fungal & - Pulmonary fibrosis \\
- Hyperleukocytosis and pulmonary & & - Acute respiratory distress \\
leukostasis & & syndrome \\
- Acute lysis pneumopathy & & Pulmonary embolism \\
Superior vena cava and superior & & Pulmonary oedema \\
mediastinal syndrome & & Alveolar haemorrhage \\
& & Acute capillary leak syndrome \\
& & Graft-versus-host disease \\
& & Impaired growth and \\
& & development \\
\hline
\end{tabular}




\section{Pulmonary Malignancies and Complications of Treatment}

\section{Complications Directly Resulting from Malignancy}

\section{Primary and Metastatic Lung Tumours}

Primary lung tumours are extremely rare, representing only $0.2 \%$ of all childhood cancers $[4,5]$. The vast majority of pulmonary malignancies are in fact metastases, characteristically located in peripheral lower lung segments as well-circumscribed nodules and most commonly associated with Wilm's tumour and osteosarcoma [46]. While parenchymal lesions exhibit a more insidious and non-specific presentation, endotracheal and endobronchial lesions often present with unilateral wheeze due to obstruction and can be easily misdiagnosed as asthma [7]. Despite the rarity and non-specific clinical presentation of most lung tumours, malignant disease should be considered in children with constitutional symptoms and persistent wheeze, haemoptysis, atelectasis or pneumonia who fail to respond to therapy [5].

\section{Pulmonary Infiltrates from Systemic Disease}

Hyperleukocytosis and Pulmonary Leukostasis

Hyperleukocytosis, defined by a leukocyte count greater than $100 \times 10^{9} / \mathrm{L}$, occurs in up to $20 \%$ of initial presentations of acute lymphoblastic leukaemia (ALL) and $15 \%$ of acute myeloid leukaemia (AML) $[1,8]$. Excess leukaemic aggregates can lead to pulmonary leukostasis, a life-threatening complication where cellular occlusion of the pulmonary vasculature leads to hypoxia and acute respiratory distress $[9,10]$. While this condition only occurs in up to $6 \%$ of children with acute hyperleukocytic leukaemias, associated respiratory failure is one of the most common causes of early mortality in this setting $[11,12]$.

The pathophysiological basis of hyperleukocytosis-induced pulmonary leukostasis is related to the stasis of hyperviscous blood from elevated leukocrit [1]. Aggregates of rigid blasts cause plugging of the microvasculature and associated oxygen defects, potentiating pulmonary endothelial injury, haemorrhage and tissue hypoxia $[8,13,14]$. As such, the risk of respiratory complications increases with the degree of leukocytosis [15]. However, not all children with high leukocyte counts, such as those with chronic leukaemias, develop this complication due to the morphology and maturity of the leukocytes. Children with AML are at greatest risk of pulmonary leukostasis and tend to develop respiratory distress at lower leukocyte counts than those with ALL [9, 12]. This is because myeloblasts are larger and release pro-inflammatory cytokines with specific adhesion molecules that facilitate aggressive invasion of pulmonary endothelium $[12,16]$.

Pulmonary leukostasis is empirically diagnosed when children with leukaemia present clinically with hyperleukocytosis and respiratory distress. Though often 
non-specific, it can manifest in dyspnoea, pleuritic chest pain and hypoxaemia and lead to right ventricular failure [17]. Chest X-rays may be normal or may show alveolar consolidation and diffuse reticulonodular infiltrates that may resemble pneumonia or interstitial oedema [18]. Computed tomography (CT) radiography may demonstrate thickening of the bronchovascular bundles, prominence of peripheral pulmonary arteries and ground-glass opacities due to leukaemic cell infiltration $[1,17,18]$. Definitive management remains controversial; however, hyperhydration, urate oxidase, low-dose chemotherapy and consideration of leukopheresis may be beneficial in children with extremely high leukocyte counts [12, 15, 19].

\section{Acute Lysis Pneumopathy}

Upon initiation of chemotherapy, children with severely worsening hypoxaemia may be symptomatic of 'acute lysis pneumopathy'. This is a rare complication of myelomonocytic and monocytic leukaemias, where lysis of leukaemic cells trapped in the lungs causes diffuse alveolar damage [3,20,21]. Management considerations include temporary discontinuation of chemotherapy, steroids and transfusions [22, 23].

\section{Pulmonary Infiltrate in Leukaemia and Lymphoma}

Outside the context of hyperleukocytosis, post-mortem evidence has also found diffuse and focal leukaemic infiltration of lung parenchyma, pleura, alveoli, bronchi, and pulmonary vessels in patients with leukaemia and lymphoma [24, 25]. However, symptomatic pulmonary disease due to isolated leukaemic cell infiltrates is uncommon $[3,26]$.

\section{Langerhans Cell Histiocytosis (LCH)}

Pulmonary involvement in LCH occurs in up to $50 \%$ of children with multisystem disease and very rarely as primary pulmonary LCH [2, 27-29]. Pathologic accumulation of Langerhans cells admixed with eosinophils, macrophages, and T lymphocytes typically exhibits a bronchocentric infiltration pattern [5, 30]. This is best assessed on high-resolution CT, typically showing reticulonodular opacities in the mid to upper zones with sparing of the costophrenic angles [29, 31]. With progressive destruction of the bronchioles, lesions develop more a diffuse, cystic and fibrotic 'honeycombing' appearance $[2,31]$.

\section{Extra-Pulmonary Tumours}

Mediastinal tumours can compress the tracheobronchial tree and pulmonary vessels causing respiratory insufficiency, superior vena cava (SVC) syndrome and/or superior 
mediastinal syndrome $[1,6]$. The low intraluminal pressure and delicate wall of the SVC in children with smaller thoracic capacity renders it particularly vulnerable, especially to rapidly enlarging masses of haematological malignancies such as Hodgkin lymphoma, T-cell leukaemia and germ cell tumours [1]. Respiratory manifestations include cough, stridor, chest pain, dyspnoea, orthopnoea, and aversion to the prone position [11]. In these children at risk of cardiorespiratory collapse, urgent assessment of haemodynamic compromise and airway patency such as with a prone $\mathrm{CT}$ is essential.

Extra-thoracic space-occupying tumours such as Ewing's sarcoma can also impair normal diaphragmatic excursion and mechanically compromise the respiratory system [1]. Rarely, intracranial tumours can lead to central hypoventilation syndromes or sleep apnoea $[1,2]$.

\section{Infectious Complications and Their Relationship to Immune Function}

Malignancy and cytotoxic therapies cause multifactorial immune defects (Fig. 1) including severe myelosuppression, multi-organ dysfunction and compromise of the mucosal integrity of the respiratory system [35]. Thus, children with cancer undergoing chemotherapy are at high risk of infections from typical and opportunistic viral, bacterial and fungal pathogens (Table 2) [39, 40]. Respiratory infections carry significant morbidity and mortality, particularly during severe neutropenia and intensive induction therapy [41]. Infection-related acute respiratory failure has been reported as a common cause of ICU admission and mortality in paediatric oncology [1, 42].

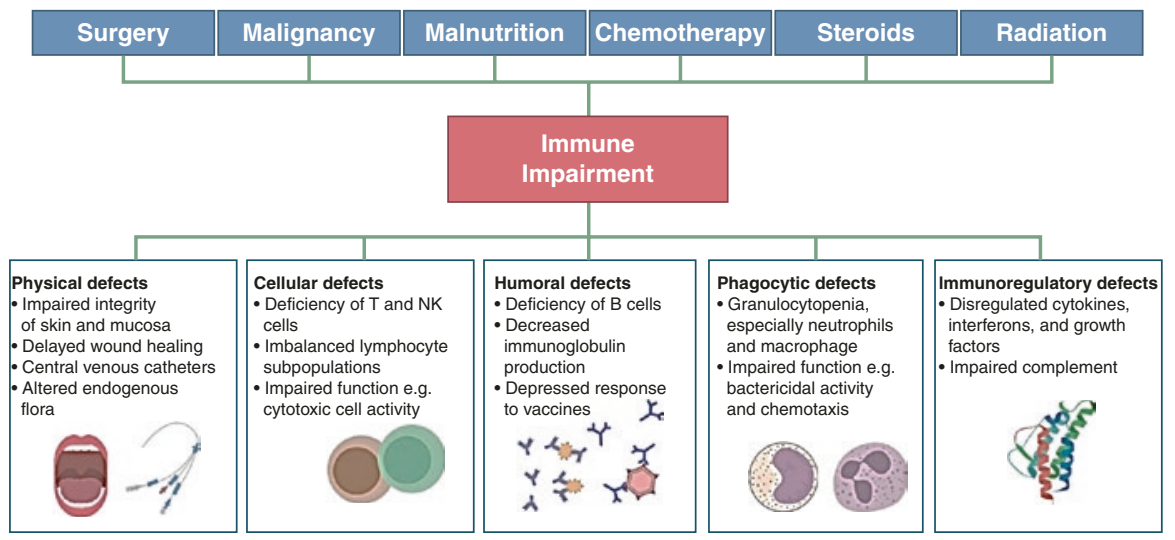

Fig. 1 Immune defects due to malignancy and cytotoxic therapy [32-34] 
Table 2 Common respiratory pathogens in childhood malignancy [1, 24, 36-38]

\begin{tabular}{l|l|l}
\hline & Common organisms & Risk factors \\
\hline Protozoa & Toxoplasma gondii & Lymphopenia \\
\hline Fungi & $\begin{array}{l}\text { Aspergillus species } \\
\text { Candida } \\
\text { Zygomcetes } \\
\text { Pneumocystis jiroveci }\end{array}$ & $\begin{array}{l}\text { Chronic immunosuppression } \\
\text { Severe neutropenia }<100 / \mu \mathrm{L} \\
\text { Prolonged neutropenia }>7 \text { days } \\
\text { High-dose corticosteroids }\end{array}$ \\
\hline \multirow{2}{*}{ Bacteria } & $\begin{array}{l}\text { Respiratory syncytial virus, rhinovirus, influenza, } \\
\text { parainfluenza, human metapneumovirus, } \\
\text { adenovirus, cytomegalovirus, varicella zoster, } \\
\text { herpes simplex }\end{array}$ & $\begin{array}{l}\text { Lymphopenia } \\
\text { Young age <2 years old }\end{array}$ \\
& $\begin{array}{l}\text { Pseudomonas, Mycoplasma, Legionella, } \\
\text { Chlamydia, Mycobacteria, Haemophilus } \\
\text { influenzae } \\
\text { Streptococcus, Staphylococcus }\end{array}$ & $\begin{array}{l}\text { Neutropenia, 7-12 days } \\
\text { post-chemotherapy } \\
\text { Skin infections }\end{array}$ \\
\hline
\end{tabular}

Table 3 Differentials for pulmonary infiltrates found in childhood malignancy

\begin{tabular}{l|l}
\hline $\begin{array}{l}\text { Pulmonary } \\
\text { infiltrate }\end{array}$ & Differentials/causes \\
\hline Local & $\begin{array}{l}\text { Infection-bacterial (early) or fungal (late) } \\
\text { Tumour } \\
\text { Pulmonary embolus }\end{array}$ \\
\hline Diffuse & $\begin{array}{l}\text { Systemic disease infiltrate (Langerhan cell histiocytosis, leukaemia, lymphoma) } \\
\text { Pulmonary haemorrhage } \\
\text { Cardiogenic and non-cardiogenic pulmonary oedema } \\
\text { Pulmonary leukostasis } \\
\text { Diffuse alveolar damage } \\
\text { Viral pneumonia } \\
\text { Drug or radiation toxicity }\end{array}$ \\
\hline Late & $\begin{array}{l}\text { Immune reconstitution resulting in fibrosis } \\
\text { Pneumocystosis }\end{array}$ \\
\hline
\end{tabular}

In a neutropenic child, pulmonary infections can be subclinical due to immune failure to mount an inflammatory exudative response [39, 43, 44]. Chest radiography can also be normal, with studies suggesting it is only useful for evaluating a symptomatic child or monitoring treatment response $[43,45]$. While bronchoalveolar lavage is a valuable diagnostic tool, it may be of less value if patients have already commenced empirical broad-spectrum antimicrobials [46]. CT-guided fineneedle biopsy can also play a role; however, the gold standard remains thoracoscopic or open lung biopsy [47]. This is usually reserved for diagnostically challenging cases that are non-responsive to therapy. Of note, a wide range of differentials of pulmonary infiltrates can also mimic infections (Table 3) [48].

While respiratory infections are a common cause of fevers in children with cancer, their long-term pulmonary sequelae remains unclear. In childhood leukaemia survivors, reduced lung volumes and impaired exercise capacity have been correlated with recurrent chest infections [49]. Impaired cellular and humoral immune function have also been found to persist $>1$ year post-therapy depending on treatment intensity $[44,50]$. 


\section{Non-Infectious Complications}

\section{Chemotherapy}

The respiratory system is particularly susceptible to drug toxicity during childhood due to ongoing physiological development, its rich vascularity and large contact surface area. As summarised in Table 4, the presentation and pathogenesis of injury varies with specific drugs but is generally hypothesised to arise from several key mechanisms: (1) oxidative injury to endothelium and pneumocytes, (2) cytokine induction and inflammation, (3) proteinolytic destruction, (4) immune dysregulation and/or (5) idiosyncrasy [35, 55-57].

Pulmonary-toxic chemotherapies can cause acute pulmonary and pleural reactions such as hypersensitivity pneumonitis, pleural effusions and lung infiltrates. Hypersensitivity reactions are most frequently reported with bleomycin and methotrexate and usually manifest as reversible eosinophilic or desquamative interstitial

Table 4 Common chemotherapeutic agents associated with pulmonary complications [2, 51-54]

\begin{tabular}{|c|c|c|c|}
\hline Drug class & Key agents & Main uses & Pulmonary complication \\
\hline Antibiotics & $\begin{array}{l}\text { Bleomycin } \\
\text { Doxorubicin }\end{array}$ & $\begin{array}{l}\text { HD, lymphomas } \\
\text { Germ cell tumours }\end{array}$ & $\begin{array}{l}\text { Hypersensitivity pneumonitis, } \\
\text { interstitial pneumonitis } \\
\text { Pulmonary fibrosis, ARDS }\end{array}$ \\
\hline Alkylating agent & $\begin{array}{l}\text { Busulfan } \\
\text { Melphalan } \\
\text { Cyclophosphamide } \\
\text { Ifosfamide }\end{array}$ & $\begin{array}{l}\text { BMT } \\
\text { BMT } \\
\text { Widely used }\end{array}$ & $\begin{array}{l}\text { Late-onset pulmonary fibrosis } \\
\text { Early- or late-onset } \\
\text { pneumonitis, bronchospasm, } \\
\text { diffuse pulmonary } \\
\text { haemorrhage }\end{array}$ \\
\hline Nitrosoureas & $\begin{array}{l}\text { BCNU (carmustine) } \\
\text { CCNU (lomustine) }\end{array}$ & $\begin{array}{l}\text { BMT, CNS } \\
\text { tumours }\end{array}$ & Pulmonary fibrosis \\
\hline Antimetabolite & $\begin{array}{l}\text { Methotrexate } \\
\text { Mercaptopurine } \\
\text { Cytarabine } \\
\text { Gemcitabine }\end{array}$ & $\begin{array}{l}\text { ALL, non-HL } \\
\text { ALL } \\
\text { AML, non-HL } \\
\text { HD }\end{array}$ & $\begin{array}{l}\text { Hypersensitivity pneumonitis, } \\
\text { interstitial and alveolar } \\
\text { infiltrate, pleural effusion } \\
\text { Capillary leak syndrome, } \\
\text { NCPE } \\
\text { NCPE, capillary leakage, } \\
\text { diffuse alveolar damage and } \\
\text { haemorrhage, ARDS }\end{array}$ \\
\hline Plant alkaloids & $\begin{array}{l}\text { Vinblastine } \\
\text { Vincristine }\end{array}$ & $\begin{array}{l}\text { ALL, lymphoma } \\
\text { Low-grade glioma }\end{array}$ & $\begin{array}{l}\text { Bronchospasm } \\
\text { Neurotoxicity-related vocal } \\
\text { cord paralysis and airway } \\
\text { compromise }\end{array}$ \\
\hline \multirow[t]{3}{*}{ Newer agents } & Rituximab & $\begin{array}{l}\text { Lymphoma, } \\
\text { post-transplant } \\
\text { lymphoproliferative } \\
\text { disease }\end{array}$ & $\begin{array}{l}\text { Acute interstitial pneumonia, } \\
\text { lung fibrosis }\end{array}$ \\
\hline & Transretinoic acid & APL & $\begin{array}{l}\text { Retinoic acid syndrome, } \\
\text { diffuse pulmonary infiltrate }\end{array}$ \\
\hline & Taxanes & Experimental & $\begin{array}{l}\text { Interstitial pneumonitis, } \\
\text { diffuse alveolar damage } \\
\text { Pleural effusion }\end{array}$ \\
\hline
\end{tabular}


pneumonitis $[48,55,58]$. However, the most pertinent and concerning pulmonary complications of chemotherapy are interstitial pneumonitis and permanent fibrosis. These have been found to cause premature mortality, impaired diffusion, and limited exercise capacity in adult life $[2,58]$. While children may be asymptomatic during treatment, persistent subclinical abnormalities indicate potential for decompensation with ageing [59].

In the absence of pathognomonic findings, drug-induced lung toxicity is a diagnosis of exclusion [1]. Typical features include:

- Clinical signs and symptoms of hypoxaemia, dry cough, crackles, and exertional dyspnoea

- Restrictive pattern on pulmonary function testing and impaired diffusion capacity [56]

- Diffuse alveolar or interstitial infiltrates on CT imaging

- Interstitial thickening, chronic inflammatory cell infiltrate (including eosinophils in hypersensitivity reactions), and type 2 pneumocyte hyperplasia on pathology $[2,35,51]$

Hyperinflation and obstructive defects secondary to airway inflammation and oedema may also be observed [1].

Specific offending agents are difficult to isolate in polytherapeutic regimes. Synergistic toxicity has been observed when specific chemotherapies are combined with radiation therapy (e.g., bleomycin, busulfan) or oxygen (bleomycin). Furthermore, certain drug combinations, particularly nitrosoureas and cyclophosphamides, can potentiate toxicity at lower doses [60].

Management is primarily reactive with cessation of the offending chemotherapy agent and supportive care with bronchodilators, antibiotics, airway clearance and/or supplemental oxygen $[2,61]$. Limited evidence suggests corticosteroids may relieve hypersensitivity reactions, though steroid withdrawal must be gradual to avoid reactivation [55, 61]. Early drug-induced pneumonitis is largely reversible, emphasising the importance of lung function monitoring and prompt diagnosis [55, 62]. However, pulmonary function and radiographic abnormalities often persist into adulthood and are associated with premature lung disease and mortality [2, 58, 59, 62].

Bleomycin is a cytotoxic antibiotic used for paediatric lymphomas and germ cell tumours. It is the most widely recognised cause of drug-related lung injury, affecting up to $72 \%$ of children treated with bleomycin with a $1-2 \%$ mortality $[58,61-66]$. Bleomycin has been reported to cause both acute hypersensitivity reactions and late interstitial pneumonitis and fibrosis within 1 year of treatment $[55,67,68]$. Vascular toxicities involving intimal fibrosis and pulmonary hypertension have also been observed [73].

The pathogenesis of bleomycin lung toxicity primarily involves oxidative damage to cell DNA by free radicals from bleomycin-Fe complexes [69-71]. In the absence of its detoxifying enzyme, bleomycin hydrolase [72, 73], bleomycin can accumulate in the lungs to cause proteolysis of lung parenchyma and direct endothelial injury. Subsequent vascular permeability results in interstitial oedema and the formation of hyaline membranes as plasma proteins and fluid enters alveoli [2]. Cytokines (primarily TNF- $\alpha$, IL-1B and TGF-B) further potentiate endothelial damage and type 1 pneumocyte apoptosis $[61,74,75]$. Finally, inflammatory cell influx 
and immune processes lead to fibrosis of the lung parenchyma and bronchi [2]. Tissue pathology has revealed type 2 pneumocyte hyperplasia, haemorrhage and oedema consistent with diffuse alveolar damage [55].

Important iatrogenic risk factors for bleomycin-induced pulmonary toxicity include cumulative doses greater than $400 \mathrm{IU} / \mathrm{m}^{2}$, concomitant radiotherapy, highdose oxygen therapy and certain chemotherapies (cyclophosphamide, vincristine, doxorubicin, cisplatin, methotrexate) [62]. Younger children and patients with impaired renal function limiting drug excretion are at greater risk and need to be monitored with higher caution $[35,58,71,76]$.

Patients with acute toxicity typically present with exertional dyspnoea and a dry cough. Reduced $\mathrm{DL}_{\mathrm{CO}}$ is considered the most sensitive marker of bleomycin-induced fibrosis, where therapy cessation is indicated if $<60 \%$ of baseline $[2,62]$. However, it is important to note that $\mathrm{DL}_{\mathrm{CO}}$ abnormalities may only become apparent 6 months post-therapy. CT radiography can be a useful adjunct for monitoring disease progression and typically demonstrates fine nodular infiltrates with a bibasilar reticular pattern [55]. While bleomycin injury is generally associated with restrictive defects and impaired diffusion, a recent study in children treated with contemporary, lowerdose bleomycin regimens found hyperinflation and obstructive lung disease to be most common up to 12 years post-diagnosis $[2,65,66]$. It has been hypothesised that these abnormalities could be due to airway inflammation from bleomycininduced pro-inflammatory cytokines or a bridging process of early fibrosis.

Alkylating agents are a broad class of chemotherapies known to cause chronic lung injury. In children undergoing pre-BMT conditioning, busulfan can cause acute pneumonitis and alveolar haemorrhage but is most recognised for insidious pulmonary fibrosis up to 10 years post-therapy [71, 77-79]. Typical pathological findings include type 2 pneumocyte hyperplasia and lymphocyte and plasma cell infiltrate. Busulfan-induced fibrosis is typically associated with higher mortality as compared to other chemotherapies, though it does not appear to be dose related [80].

Nitrosoureas are alkylating and carbamylating agents with established dosedependent pulmonary toxicity. Injury occurs in 50\% of those with cumulative doses greater than $1500 \mathrm{mg} / \mathrm{m}^{2}$ and can manifest as early as 1 month into therapy. Lateonset fibrosis has also been reported in 20-30\% of BCNU-treated patients [76] and is associated with significant premature mortality [58].

Cyclophosphamide injury occurs through lipid peroxidation of phospholipid membranes and free radical formation like bleomycin [71]. Toxicity predominantly presents as early-onset pneumonitis within 6 months of exposure and is reversible with drug cessation and steroid therapy $[2,58]$. Less than $1 \%$ of patients exhibit late-onset pneumonitis that progresses to fibrosis [35].

\section{Surgery}

Surgical interventions for lung tumours include pneumectomy, lobectomy, pulmonary metastasectomy and wedge resection [81-83]. Few studies to date have examined post-surgical pulmonary dysfunction in the context of paediatric malignancies. However, virtually all paediatric case series demonstrate good 
long-term outcomes even with aggressive surgery in early childhood [84-86]. It is hypothesised that preserved lung function and capacity post-resection are due to hyperplastic compensatory mechanisms and hyperinflation of remaining tissue [87-89].

Complications of thoracic surgery, however, may include irreversible airway obstruction due to dysanapsis [84, 90], diaphragmatic hernia or phrenic nerve injury [91] and post-pneumonectomy syndrome due to herniation of flexible mediastinal structures into a vacant pleural cavity [88]. Progressive hyperinflation can lead to bronchomalacia and predispose to pulmonary infections [92, 93]. Damage to the chest wall and musculoskeletal deformities, particularly scoliosis, can also restrict thoracic excursion and pulmonary growth and function [94]. Thus, both functional lung testing and imaging are essential in follow-up and management.

\section{Thromboembolic Complications}

Pulmonary embolism (PE) is a rare but life-threatening complication that has been reported in $1.9-4.5 \%$ of paediatric oncology patients [95-97]. While the etiopathogenesis is difficult to determine, thromboembolic events may be associated with increased thrombin generation with malignancy, tumour emboli from cell lysis, altered haemostasis due to L-asparaginase use, acquired thrombophilia in the early post-transplant period, thrombogenic intravenous hyperalimentation and/or endothelial injury with central line use [98-100]. In children with acute respiratory failure associated with PE, studies suggest prompt thrombolytic therapy is effective for reducing early morbidity [95]. However, asymptomatic and undetected PEs do not appear to adversely affect patient outcomes [97].

\section{Growth and Development}

Children undergoing cancer treatment inevitably suffer significant disruption to normal lung growth and development due to surgery, cytotoxic therapy, chronic immunosuppression, prolonged steroid use and nutritional stress [101]. Children are at risk of impaired alveoli development, which can lead to respiratory insufficiency $[102,103]$. Abnormal growth of musculoskeletal structures can also decrease chest wall compliance and further restrict pulmonary function [58]. Other respiratory morbidities can be associated with cardiopulmonary compromise, limited exercise tolerance and infections due to delayed immune reconstitution. Notably, studies have found the cumulative incidence of pulmonary morbidities increases with time since diagnosis [59]. This suggests that early childhood injury may cause late-onset respiratory complications and potentially accelerate physiological lung function decline. 


\section{Pulmonary Complications of Blood and Bone Marrow Transplantation}

Since the first reported successful application of blood and bone marrow transplantation (BMT) to treat leukaemia in 1959 [104], BMT has been increasingly utilised across a range of conditions with high mortality rates [105]. Despite advances in BMT over recent decades [106], pulmonary complications continue to be a significant cause of ongoing morbidity and mortality [101]. Pulmonary complications are estimated to occur in $25 \%$ of paediatric post-BMT patients and are associated with a close to $50 \%$ increase in risk of mortality $[101,107]$. Long-term follow-up studies of BMT survivors have documented the occurrence of both obstructive and restrictive lung disease following transplantation [108-110].

Multiple mechanisms are responsible for post-BMT pulmonary injury. Damage resulting from chemotherapy (including conditioning agents busulfan and cyclophosphamide) [59] has been discussed previously in this chapter, and lung injury resulting from irradiation is described in chapter "Pulmonary Complications of Mental Health Problems". Additional mechanisms through which lung injury occurs include immune-mediated events (e.g., graft-versus-host disease) as well as effects of ongoing immunosuppression [101]. A tri-phasic model of injury for chronic lung injury post-BMT has been proposed, and steps include:

1. Alloantigen recognition occurs and inflammatory cells proliferate.

2. Persistence of the inflammatory phase causes lymphocyte migration into the mucosa of the airways and result in epithelial cell damage.

3. Proliferation of lung fibroblasts then increases production and deposition of collagen [111].

Post-BMT pulmonary complications can be categorised into infectious and noninfectious complications and further separated into early (in the first 100 days postBMT) and late (after 100 days post-BMT) as shown in Table 5 and Fig. 2. Infectious

Table 5 Infectious and non-infectious pulmonary complications post-BMT according to timing post-transplantation $[112,113]$

\begin{tabular}{l|l|l}
\hline & Infectious complications & Non-infectious complications \\
\hline $0-100$, days, & Bacterial infections & Acute graft-versus-host disease \\
early-, & Fungal infections & Mucositis \\
post-BMT & $\begin{array}{l}\text { Pneumocystis jirovecii } \\
\text { New community viral infections } \\
\text { Viral reactivation- } \\
\text { cytomegalovirus (CMV), } \\
\text { Epstein-Barr virus (EBV) }\end{array}$ & $\begin{array}{l}\text { Idiopathic pneumonia syndrome } \\
\text { Pulmonary veno-occlusive disease }\end{array}$ \\
\hline $\begin{array}{l}\text { Late }>100 \text { days } \\
\text { post-BMT }\end{array}$ & $\begin{array}{l}\text { Late viral infections-adenovirus, } \\
\text { HHV-6, human metapneumovirus } \\
\text { (HMPV) }\end{array}$ & $\begin{array}{l}\text { Graft-versus-host disease (GVHD) } \\
\text { Interstitial lung disease } \\
\text { Post-transplant lymphoproliferative } \\
\text { disease (PTLD) } \\
\text { Bycobacterial disease } \\
\text { Atypical pneumonia-Legionella }\end{array}$ \\
\hline
\end{tabular}




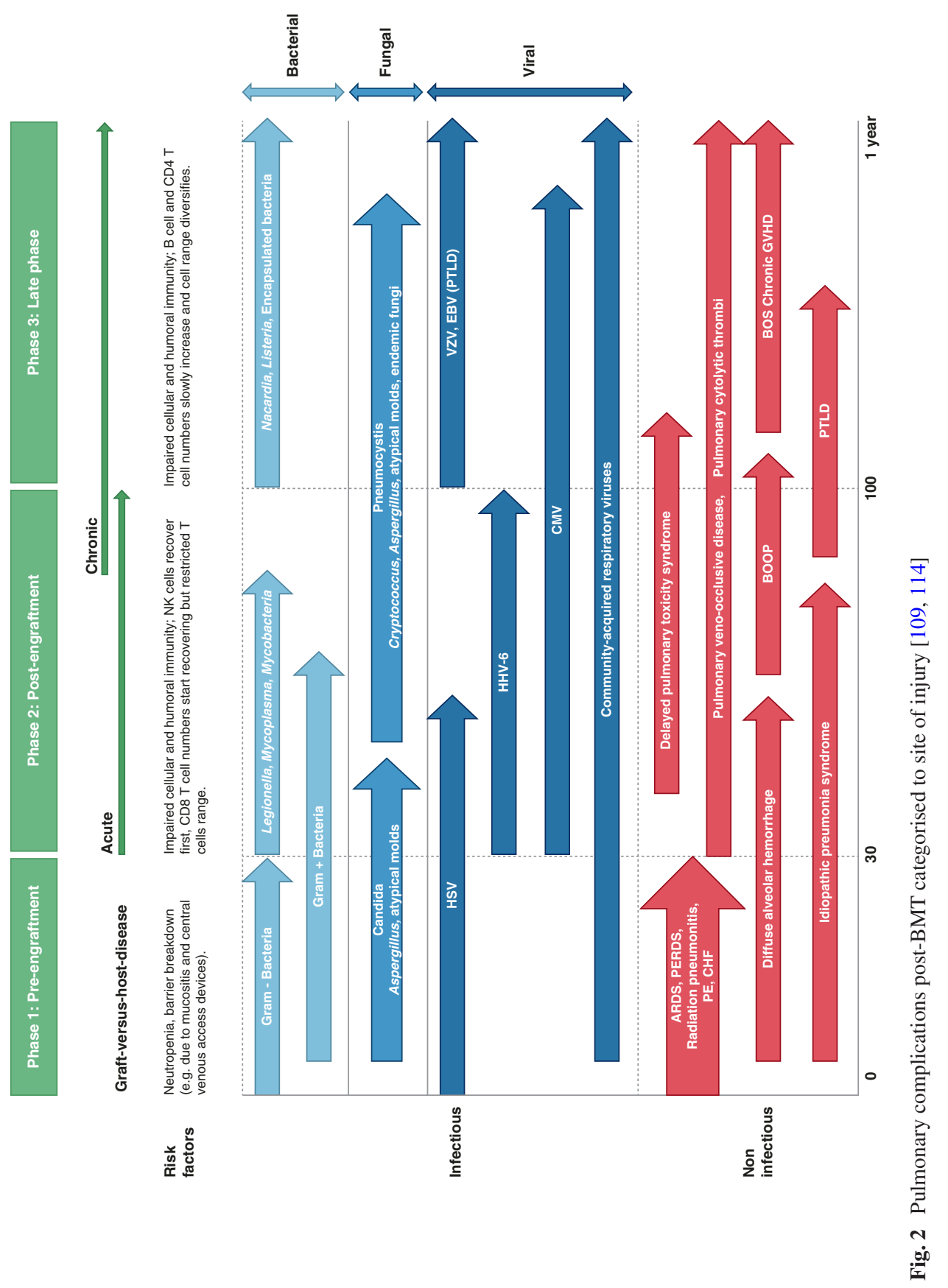


complications play an important role in the first months following transplantation, and non-infectious aetiologies play a more prominent role in the months and years after BMT [101]. Another classification system is based on the site of lung injury: lung parenchyma, airway epithelium and vascular endothelium as shown in Fig. 3 [101].

\section{Infectious Complications and Their Relationship to Immune Function}

Infectious complications are common post-BMT and can occur in allogeneic and autologous recipients. However, they are more common in allogeneic transplant recipients, and this is believed to be secondary to GVHD and immunosuppressive medication use [115]. Additional known risk factors for infection post-BMT include allogeneic transplant, HLA mismatch, more advanced disease prior to BMT, unrelated donors, immunosuppression, high-dose chemotherapy/radiotherapy for conditioning and delayed engraftment [106].

The infectious complications occurring in post-transplant can be classified by time post-transplant according to the following three phases:

1. Phase 1-The pre-engraftment stage (up to 30 days post-BMT) includes the time in which the neutrophil count recovers.

2. Phase 2-Post-engraftment phase (30-100 days post-BMT).

3. Phase 3-The late phase (>100 days post-BMT) [106, 112, 115].

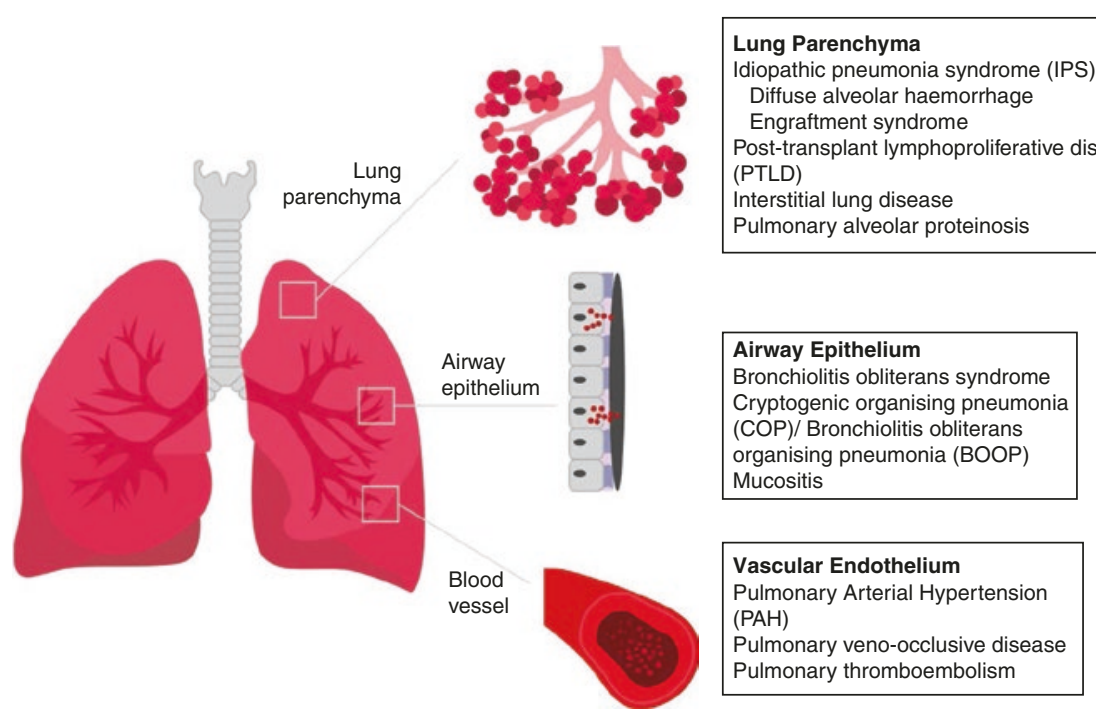

Fig. 3 Timeline of infectious and non-infectious complications post-BMT. Figure adapted from $[106,115,116]$ 
During the pre-engraftment phase, neutropenia and interruption of the mucocutanous barrier place patients at risk of bacteraemia as well as fungal infections (mould and yeast species) $[112,115]$. Pseudomonas aeruginosa and Klebsiella pneumoniae are important gram-negative organisms, which causes bacteraemia in the preengraftment stage. Staphylococcus aureus, Streptococcus viridans and Enterococcus spp. are the common gram-positive organisms seen in this phase [115, 117].

Infections during the post-engraftment phase are predominately related to deficiencies in cell-mediated immunity. Additional risk factors are graft-versus-host disease and immunosuppressive therapy. The major pathogens during this phase are the herpes viruses (especially CMV and EBV), Pneumocystis jirovecii and Aspergillus species.

The late phase involves gradual immune system rebuilding as well as the tapering of immunosuppressive agents [112]. During this time the primary pathogens are CMV, EBV, adenovirus and encapsulated bacteria (e.g., Streptococcus pneumoniae). GVHD severity is again a risk factor for infection in this phase [106]. Though opportunistic infections rarely occur late post-BMT, cases are reported which suggests that transplantation itself (in the absence of GVHD or immunosuppression) can cause long-term immune dysfunction [115]. One of the factors influencing this is that for restoration of humoral immune function, post-BMT rebuilding of stores of naïve B cells and memory B cells is necessary. Hence all BMT patients are at risk of opportunistic infections from encapsulated bacteria and viruses for up to 1 year postBMT [115].

\section{Non-Infectious Complications}

\section{Mucositis}

Oral mucositis is a well-known and common early complication affecting the majority of patients undergoing BMT [112]. Mechanisms resulting in development of mucositis include intensive chemotherapy, irradiation, bacterial colonisation, increased inflammatory cytokine and oxidative stress [118]. Compromised mucociliary clearance then leads to the development of respiratory pathology such as sinusitis, oropharyngeal haemorrhage and aspiration pneumonia. In more severe cases, it can result in upper airway obstruction due to laryngeal or epiglottic oedema [112].

\section{Pulmonary Oedema}

Pulmonary oedema is a common post-BMT complication and typically occurs in the second or third week post-transplantation [113]. Possible mechanisms for development include increased hydrostatic pressure (from intravenous rehydration or parenteral nutrition), cardiac dysfunction (anthracyclines), nephrotoxicity (cyclosporin), increased pulmonary capillary permeability (sepsis) or pulmonary toxicity 
(chemotherapy or irradiation) [112]. Clinical findings are typical of those seen in pulmonary oedema affecting non-BMT patients dyspnoea, tachypnoea and hypoxia. Radiography may show bilateral infiltrates, Kerley B lines and pleural effusions. Diuresis remains the mainstay of treatment [113].

\section{Immune-Mediated Phenomena}

Idiopathic pneumonia syndrome (IPS) typically occurs in the peri-engraftment period, weeks to months after BMT [114]. The definition of IPS has recently been updated in an American Thoracic Society (ATS) Research Statement [114]. The ATS now defines IPS as "an idiopathic syndrome of pneumopathy after BMT, with evidence of widespread alveolar injury and in which infectious aetiologies and cardiac dysfunction, acute renal failure or iatrogenic fluid overload have been excluded" [114]. The clinical presentation of IPS is with dry cough, hypoxia and increasing dyspnoea. The incidence in paediatric BMT is estimated at 5-10\%, and the reported mortality approaches $75 \%[119,120]$. The pathophysiology of IPS is still not well understood; however, the most likely factors at play are cytotoxic and immunemediated insults to the lungs [114]. Biopsy is often not possible due to the clinical instability of patients as well as the high mortality risk of the procedure in early transplant $[113,114]$. Current treatment includes supportive care and systemic corticosteroid therapy $[101,114]$.

Clinical entities included in the IPS definition are acute interstitial pneumonitis (AIP), diffuse alveolar haemorrhage (DAH) and peri-engraftment respiratory distress syndrome (PERDS) $[101,114]$. DAH begins in the pre-engraftment period (most commonly in the second or third week) [113], and a higher rate of DAH is seen in patients with mucopolysaccharidosis (MPS) [118]. Typical clinical features are increasing dyspnoea, dry cough, and hypoxaemia [113]. Fevers may or may not occur. Bronchoalveolar lavage (BAL) reveals increasingly blood-stained fluid; however, haemoptysis is not typically seen [114]. PERDS develops in the first 5 days post-engraftment during neutrophil recovery [114] [121]. Classically patients present with fever, rash and hypoxaemia and dyspnoea due to non-cardiac pulmonary oedema [121]. PERDS has been observed in non-myeloablative regimens that avoid conditioning-associated toxicities. This would suggest that white cell recovery itself and the associated release of soluble factors are implicated in the aetiology of PERDS [121].

Graft-versus-host disease (GVHD), an immune-mediated disease, plays an important role in complications in multiple organ systems in BMT recipients [122]. Lung biopsy is not often performed in BMT patients, and therefore the extent of GVHD and level of pulmonary tissue damage are not as clearly understood as that of other organ systems [122]. Historically the lungs were not believed to be a typical target for acute GVHD; however, data now reveals that this is the case for a subgroup of patients [122]. Recent National Institute of Health (NIH) working groups have sought to better define lung chronic GVHD [123, 124]. Previously, the only diagnostic pulmonary manifestation of cGVHD was biopsy-proven constric- 
tive bronchiolitis obliterans $(\mathrm{CBO})$; however, bronchiolitis obliterans syndrome (BOS), a clinical entity, is now included in the NIH diagnostic criteria for lung cGVHD [123].

BOS is the most common late pulmonary complication and the most common obstructive lung disease in BMT patients [109, 110, 112]. BOS occurs in 4-9\% of the paediatric post-BMT population [109] with mortality reported to range from $11 \%$ to $67 \%[109,125]$. Symptoms of BOS typically present months after BMT and include cough, wheeze and exertional dyspnoea $[109,125]$. The diagnosis of BOS is largely based on high-resolution computed tomography (HRCT) findings (air trapping and mosaic attenuation) and an obstructive pattern on pulmonary function testing (PFTs). Confirmatory lung biopsy is not commonly required [101, 112]. The proposed NIH criteria for lung GVHD are:

1. FEV1/FVC $<$ lower limit of normal

2. FEV $1<$ lower limit of normal with $\geq 10 \%$ decline over less than 2 years

3. Absence of respiratory infection

4. Evidence of gas trapping on PFTs or air trapping, small airway thickening or bronchiectasis on HRCT

In the presence of distinctive GVHD of another organ system, the fourth criteria does not need to be met. If BOS is the only manifestation of cGVHD and no other organ system is involved, then a lung biopsy is necessary for diagnosis [123].

$\mathrm{CBO}$ is a pathological diagnosis and is otherwise known as bronchiolitis obliterans or obliterate bronchiolitis by clinicians [126]. It is caused by fibrosis and subsequent obliteration of the peripheral airway lumen due to insults such as viral infections, immune reactions from transplanted immune cells and drug toxicity [101]. Risk factors for development in post-BMT populations include chronic graftversus-host disease (cGVHD), pre-transplant conditioning (e.g., busulfan), early viral infections and advanced age of recipient [112]. Treatment involves immunosuppression using oral and inhaled corticosteroids. Other medications which may have a role include azithromycin used for its anti-inflammatory properties and monoclonal antibodies such as rituximab [112]. A wide range of non-steroidal immunosuppressive agents have also been used including azathioprine, mycophenolate mofetil, calcineurin inhibitors, imatinib, and etanercept [127]. In treatmentresistant disease, lung transplantation has been used [109].

In $\mathrm{CBO}$ the fibrotic obliteration of the bronchiolar airways begins externally to the airway lumen resulting in concentric constriction and finally obliteration of the airway lumen [126]. Hence CBO is a peri-bronchiolar fibrotic process, and it can be a patchy disease making biopsy difficult [126]. While the clinical BOS classification includes $\mathrm{CBO}, \mathrm{BOS}$ also encompasses other pathological entities such as lymphocytic bronchiolitis (LB) [124, 128]. In LB, lymphocytic inflammation occurs around and infiltrates the peripheral airways; however, there is no sub-epithelial fibrosis. It has been proposed that LB may be an earlier stage in the development of CBO from several differing underlying disorders including infection [129]. CBO and LB patients present with similar clinical symptoms and have similar pulmonary function; however, those with LB respond better to treatment [128]. Bronchiolitis 
obliterans with organising pneumonia (BOOP), now also called cryptogenic organising pneumonia (COP), is a separate clinical and histological entity and is described later in this chapter [124].

Post-transplant lymphoproliferative disorder (PTLD) is a potentially fatal complication of both BMT and solid organ tumours. The risk of PTLD in BMT is lower than that in solid organ transplant, and the incidence is reported to be $0.5-$ $1 \%[122,130]$. It is most commonly reported in allogeneic transplant recipients, and risk factors are HLA mismatch, T-cell-depleted grafts and EBV-seronegative recipients matched with EBV-seropositive donors [131]. Conditioning protocols that result in T-cell depletion and in turn cause uninhibited EBV-driven B-cell production are implicated in PTLD. PTLD can be classified into four pathogenic categories:

1. Early lesions including reactive plasmacytic hyperplasia $(\mathrm{PH})$ and infectious mononucleosis (IM)-like PTLD

2. Polymorphic lesions which show disruption of nodal architecture or a destructive extra-nodal mass

3. Monomorphic PTLD which can be divided into B-cell or T-cell neoplasms

4. Hodgkin lymphoma (HL) which is an unusual form of PTLD with histology similar to classic HL [132]

The clinical presentation is typical in the first year of BMT, and monitoring of EBV viral load is important in BMT patient surveillance. Imaging often shows nodular lesions on chest X-ray or CT scan [112]. The first-line mainstay of PTLD treatment is the reduction in immunosuppression. Additional therapeutic measures typically used are anti-B-cell immunotherapy (rituximab), chemotherapy, radiotherapy and intravenous immunoglobulin [132].

\section{Endothelial Injury}

Chemotherapy agents and radiation therapy used in conditioning pre-transplantation can cause vascular inflammation and endothelial activation [133]. Endothelial activation can in turn contribute to the downregulation of anticoagulant (e.g., antithrombin, protein $\mathrm{C}$ and $\mathrm{S}$ ) and anti-inflammatory molecules resulting in thrombosis and fibrogenesis [134]. Endothelial damage causes a reduction in the production of endogenous vasodilators (e.g., nitric oxide and prostaglandin $\mathrm{I}_{2}$ ) and hence results in vasoconstriction [135].

Pulmonary hypertension (PH) post-BMT was first described in 1984 and has been subsequently described in a number of case series and is believed to be rare; however, the incidence in current BMT recipients is unknown [136]. The two entities of $\mathrm{PH}$ commonly described are pulmonary arterial hypertension (PAH) and pulmonary veno-occlusive disease (PVOD) [137]. PH in the setting of BMT may also occur secondary to left-sided heart disease, interstitial lung disease, thromboembolism, and hypoxia [138]. It is most described in allogeneic transplant for malignant infantile osteopetrosis [139]. 
Pulmonary arterial hypertension (PAH) is more commonly reported and involves the pulmonary arterioles. Clinically patients may be asymptomatic early in disease or may report non-specific symptoms such as fatigue or exertional dyspnoea. Pulmonary vasoconstriction plays an important early role, and a progressive increase of pulmonary arterial vascular resistance causes right ventricular failure [136, 138]. On histopathology, vascular proliferation and remodelling is seen in all three layers of the arterial wall $[136,140]$. PAH develops in the setting of pulmonary arteriole intimal damage, which in turn leads to smooth muscle hypertrophy and fibroblast activation.

Veno-occlusive disease is one of most significant complications arising postBMT. Pulmonary veno-occlusive disease (PVOD) is rare in comparison to hepatic veno-occlusive disease (VOD) and is often only diagnosed post-mortem [134]. In hepatic VOD in its severest form, there is often concomitant PVOD. The pathophysiology of PVOD involves post-capillary pulmonary venular obstruction resulting in pulmonary vascular congestion and right ventricular failure. PVOD symptoms typically occur weeks to months post-BMT with progressive dyspnoea being a common early symptom. Symptoms of right heart failure develop as pulmonary hypertension worsens. Cytotoxic chemotherapy and irradiation are considered the most significant risk factors for the endothelial injury that develops in PVOD [134].

Radiographic findings on chest X-ray include pulmonary vascular congestion, Kerley B lines and pleural effusions. Bilateral infiltrates may also occur [141]. C.T chest findings include interlobular septal thickening, dilated central pulmonary arteries, and ground-glass opacification [145].

The classically described features of PVOD are a normal or low pulmonary artery wedge pressure (PAWP) on right heart catheterisation [134]. Severe pulmonary artery hypertension, pulmonary oedema on chest X-ray and normal PAWP are characteristics of PVOD [142, 143]. However, not all patients fulfil the criteria, and lung biopsy is the gold standard for diagnosis [144]. Current therapy is limited; treatment options include vasodilators, defibrotide, and corticosteroids [134]. In severe PVOD, lung transplantation is considered definitive treatment; however, recurrence has been reported, and this would suggest a multifactorial aetiology with environmental factors, genetics, and perhaps systemic endothelial dysfunction plays a role in the development of PVOD [145].

\section{Restrictive Lung Disease/Interstitial Lung Disease}

Numerous studies have demonstrated the development of restrictive lung disease in post-BMT patients. The restrictive pattern on pulmonary function testing is either an isolated finding or occurs in the presence of a reduced $\mathrm{DL}_{\mathrm{CO}}[108,146-150]$. These findings are typically seen soon after bone marrow transplantation, then improve and stabilise over 12-24 months; however, lung function does not return to pre-transplant results $[108,147,149,151]$. In the majority of cases, respiratory symptoms and imaging findings are not associated with the pulmonary function 
abnormalities [147, 149, 150, 152]. The proposed mechanisms of injury involve interstitial inflammation and fibrosis resulting from irradiation, chemotherapy, immunological impairment and recurrent respiratory infections with remodelling post-injury leading to partial resolution [109].

In the setting of restrictive lung disease with clinical symptoms post-BMT, it is often difficult to determine aetiology and interstitial lung disease; infectious pneumonitis and cryptogenic organising pneumonia (COP) all need to be considered. Alkylating agents, cyclophosphamide, methotrexate and busulfan are all known to be risk factors for developing pulmonary fibrosis. Treatment with steroid may affect an improvement in clinical symptoms; however, a thorough diagnostic workup, including excluding infectious pathology, is advised [112].

In COP (previously known as BOOP) histology reveals patchy areas of consolidation and plugs of granulation tissue in the respiratory bronchioles and alveolar ducts causing chronic interstitial inflammation [124]. COP is associated with both acute and chronic GVHD. Chest radiography typically shows patchy infiltrates, and pulmonary function testing is consistent with a restrictive pattern [153]. COP often improves with corticosteroid therapy; however, the exclusion of infectious pathology is important and may necessitate bronchoscopy and alveolar lavage and in some cases lung biopsy [112].

\section{Long-Term Pulmonary Follow-Up Recommendations}

Long-term follow-up protocols are an essential component of survivorship care as a greater proportion of childhood cancer patients progress through adult life and physiological pulmonary decline.

The Children's Oncology Group long-term follow-up guidelines (2013) recommend pulmonary function testing (including spirometry and $\mathrm{DL}_{\mathrm{CO}}$ ) at least once and 2 years post-therapy, in children treated with bleomycin, nitrosoureas, thoracic surgery, and chest radiation.

For paediatric BMT survivors, ongoing follow-up with routine pulmonary function testing (spirometry, plethysmography, and $\mathrm{DL}_{\mathrm{CO}}$ ) is recommended. National Cancer Institute recommendations include pulmonary function testing postpaediatric allogeneic BMT, six monthly for the first 2 years post-transplant then yearly [154]. The role of newer respiratory function tests such as multiple-breath washout and forced oscillation technique is also being evaluated in both paediatric and adult post-BMT populations $[155,156]$.

While the long-term outcomes of subclinical abnormalities in pulmonary function testing are not yet known, this will be an important clinical issue for patients into adulthood. Long-term sequelae of other known pulmonary insults such as respiratory infections and potential prophylactic and therapeutic interventions remain critical areas for future research. 


\section{References}

1. Meyer S, Reinhard H, Gottschling S, Nunold H, Graf N. Pulmonary dysfunction in pediatric oncology patients. Pediatr Hematol Oncol. 2004;21(2):175-95. PubMed PMID: 15160517. Epub 2004/05/27. eng.

2. Turcios NL, Fink RJ. Pulmonary manifestations of pediatric diseases. Philadelphia: Elsevier Health Sciences; 2009.

3. Hildebrand F, Rosenow EC III, Habermann TM, Tazelaar HD. Pulmonary complications of leukemia. Chest. 1990;98(5):1233-9.

4. McCahon E. Lung tumours in children. Paediatr Respir Rev. 2006;7(3):191-6. PubMed PMID: 16938641. Epub 2006/08/30. eng.

5. Dishop MK, Kuruvilla S. Primary and metastatic lung tumors in the pediatric population: a review and 25-year experience at a large children's hospital. Arch Pathol Lab Med. 2008;132(7):1079-103. PubMed PMID: 18605764.

6. McCarville MB. Malignant pulmonary and mediastinal tumors in children: differential diagnoses. Cancer Imaging. 2010;10(1A):S35-41. PubMed PMID: PMC2967153.

7. Al-Qahtani AR, Di Lorenzo M, Yazbeck S. Endobronchial tumors in children: Institutional experience and literature review. J Pediatr Surg. 2003;38(5):733-6.

8. Lichtman MA, Rowe JM. Hyperleukocytic leukemias: rheological, clinical, and therapeutic considerations. Blood. 1982;60(2):279-83. PubMed PMID: 7046844. Epub 1982/08/01. eng.

9. Bunin NJ, Pui C-H. Differing complications of hyperleukocytosis in children with acute lymphoblastic or acute nonlymphoblastic leukemia. J Clin Oncol. 1985;3(12):1590-5.

10. Vernant JP, Brun B, Mannoni P, Dreyfus B. Respiratory distress of hyperleukocytic granulocytic leukemias. Cancer. 1979;44(1):264-8. PubMed PMID: 287551. Epub 1979/07/01. eng.

11. Carroll WL, Finlay JL. Cancer in children and adolescents. London: Jones \& Bartlett Learning; 2010.

12. Porcu P, Cripe LD, Ng EW, Bhatia S, Danielson CM, Orazi A, et al. Hyperleukocytic leukemias and leukostasis: a review of pathophysiology, clinical presentation and management. Leuk Lymphoma. 2000;39(1-2):1-18.

13. Cuttner J, Conjalka MS, Reilly M, Goldberg J, Reisman A, Meyer RJ, et al. Association of monocytic leukemia in patients with extreme leukocytosis. Am J Med. 1980;69(4):555-8. PubMed PMID: 6932815. Epub 1980/10/01. eng.

14. Lichtman MA, Weed RI. Peripheral cytoplasmic characteristics of leukocytes in monocytic leukemia: relationship to clinical manifestations. Blood. 1972;40(1):52-61. PubMed PMID: 4504250. Epub 1972/07/01. eng.

15. Lowe EJ, Pui C-H, Hancock ML, Geiger TL, Khan RB, Sandlund JT. Early complications in children with acute lymphoblastic leukemia presenting with hyperleukocytosis. Pediatr Blood Cancer. 2005;45(1):10-5.

16. Lester TJ, Johnson JW, Cuttner J. Pulmonary leukostasis as the single worst prognostic factor in patients with acute myelocytic leukemia and hyperleukocytosis. Am J Med. 1985;79(1):43-8. PubMed PMID: 3860006. Epub 1985/07/01. eng.

17. Tanaka N, Matsumoto T, Miura G, Emoto T, Matsunaga N, Satoh Y, et al. CT findings of leukemic pulmonary infiltration with pathologic correlation. Eur Radiol. 2002;12(1):166-74.

18. Van Buchem M, Wondergem J, Kool L, Te Velde J, Kluin P, Bode P, et al. Pulmonary leukostasis: radiologic-pathologic study. Radiology. 1987;165(3):739-41.

19. Aswanetmanee P, Edriss H, Limsuwat C. Pulmonary leukostasis as a complication of leukemia. Southwest Respir Crit Care Chronicles. 2015;3(10):17-22.

20. Hijiya N, Metzger ML, Pounds S, Schmidt JE, Razzouk BI, Rubnitz JE, et al. Severe cardiopulmonary complications consistent with systemic inflammatory response syndrome caused by leukemia cell lysis in childhood acute myelomonocytic or monocytic leukemia. Pediatr Blood Cancer. 2005;44(1):63-9.

21. Azoulay É, Fieux F, Moreau D, Thiery G, Rousselot P, Parrot A, et al. Acute monocytic leukemia presenting as acute respiratory failure. Am J Respir Crit Care Med. 2003;167(10):1329-33. 
22. Azoulay E, Canet E, Raffoux E, Lengline E, Lemiale V, Vincent F, et al. Dexamethasone in patients with acute lung injury from acute monocytic leukaemia. Eur Respir J. 2012;39(3):648-53. PubMed PMID: 21828031. Epub 2011/08/11. eng.

23. Tryka AF, Godleski JJ, Fanta CH. Leukemic cell lysis pneumonopathy. A complication of treated myeloblastic leukemia. Cancer. 1982;50(12):2763-70. PubMed PMID: 6958352. Epub 1982/12/15. eng.

24. Stover DE, Kaner RJ. Pulmonary complications in cancer patients. CA Cancer J Clin. 1996;46(5):303-20.

25. Soares FA, Landell GAM, Cardoso MCM. Pulmonary leukostasis without hyperleukocytosis: a clinicopathologic study of 16 cases. Am J Hematol. 1992;40(1):28-32.

26. Kovalski R, Hansen-Flaschen J, Lodato RF, Pietra GG. Localized leukemic pulmonary infiltrates. Diagnosis by bronchoscopy and resolution with therapy. Chest. 1990;97(3):674-8.

27. Braier J, Latella A, Balancini B, Castaños C, Rosso D, Chantada G, et al. Outcome in children with pulmonary Langerhans cell histiocytosis. Pediatr Blood Cancer. 2004;43(7): $765-9$.

28. Ha SY, Helms P, Fletcher M, Broadbent V, Pritchard J. Lung involvement in Langerhans' cell histiocytosis: prevalence, clinical features, and outcome. Pediatrics. 1992;89(3):466-9.

29. Kilborn TN, Teh J, Goodman TR. Paediatric manifestations of Langerhans cell histiocytosis: a review of the clinical and radiological findings. Clin Radiol. 2003;58(4):269-78.

30. Smets A, Mortelé K, Praeter DG, François O, Benoit Y, Kunnen M. Pulmonary and mediastinal lesions in children with Langerhans cell histiocytosis. Pediatr Radiol. 1997;27(11):873-6.

31. Picarsic J, Jaffe R. Nosology and pathology of Langerhans cell histiocytosis. Hematol Oncol Clin North Am. 2015;29(5):799-823.

32. Lehrnbecher T, Foster C, Vazquez N, Mackall CL, Chanock SJ. Therapy-induced alterations in host defense in children receiving therapy for cancer. J Pediatr Hematol Oncol. 1997;19(5):399-417. PubMed PMID: 9329461. Epub 1997/11/05. eng.

33. Wiegering V, Schlegel PG, Winkler B. Immune function in newly diagnosed children with malignancy. J Pediatr Hematol Oncol. 2012;34(7):559-64. PubMed PMID: 22735887. Epub 2012/06/28. eng.

34. Martin Ibanez I, Arce Casas A, Cruz Martinez O, Estella Aguado J, Martin Mateos MA. Humoral immunity in pediatric patients with acute lymphoblastic leukaemia. Allergol Immunopathol. 2003;31(6):303-10. PubMed PMID: 14670284. Epub 2003/12/13. eng.

35. Jenney M. Malignant disease and the lung. Paediatr Respir Rev. 2000;1(3):279-86.

36. Lehrnbecher T, Phillips R, Alexander S, Alvaro F, Carlesse F, Fisher B, et al. Guideline for the management of fever and neutropenia in children with cancer and/or undergoing hematopoietic stem-cell transplantation. J Clin Oncol. 2012;30(35):4427-38.

37. El Saleeby CM, Somes GW, DeVincenzo JP, Gaur AH. Risk factors for severe respiratory syncytial virus disease in children with cancer: the importance of lymphopenia and young age. Pediatrics. 2008;121(2):235-43. PubMed PMID: 18245413. Epub 2008/02/05. eng.

38. Hakim H, Dallas R, Zhou Y, Pei D, Cheng C, Flynn PM, et al. Acute respiratory infections in children and adolescents with acute lymphoblastic leukemia. Cancer. 2016;122(5):798805. PubMed PMID: 26700662. Pubmed Central PMCID: PMC4764417. Epub 2015/12/25. eng.

39. Furuya MEY, González-Martínez F, Vargas MH, Miranda-Novales MG, Bernáldez-Ríos R, Zúñiga-Vázquez G. Guidelines for diagnosing and treating pulmonary infiltrates in children with acute leukaemia: impact of timely decisions. Acta Paediatr. 2008;97(7):928-34.

40. Specchia G, Pastore D, Carluccio P, Mele G, Montagna MT, Liso A, et al. Pneumonia in acute leukemia patients during induction therapy: experience in a single institution. Leuk Lymphoma. 2003;44(1):97-101. PubMed PMID: 12691147. Epub 2003/04/15. eng.

41. Erdur B, Ylmaz S, Ören H, Demircioglu F, Çakmakç H, Irken G. Evaluating pulmonary complications in childhood acute leukemias. J Pediatr Hematol Oncol. 2008;30(7):522-6.

42. Keengwe I, Stansfield F, Eden O, Nelhans N, Dearlove O, Sharples A. Paediatric oncology and intensive care treatments: changing trends. Arch Dis Child. 1999;80(6):553-5. PubMed PMID: PMC1717963. 
43. Phillips B, Wade R, Westwood M, Riley R, Sutton AJ. Systematic review and meta-analysis of the value of clinical features to exclude radiographic pneumonia in febrile neutropenic episodes in children and young people. J Paediatr Child Health. 2012;48(8):641-8. PubMed PMID: 22050289. Epub 2011/11/05. eng.

44. Mustafa MM, Buchanan GR, Winick NJ, McCracken GH, Tkaczewski I, Lipscomb M, et al. Immune recovery in children with malignancy after cessation of chemotherapy. J Pediatr Hematol Oncol. 1998;20(5):451-7.

45. Roberts SD, Wells GM, Gandhi NM, York NR, Maron G, Razzouk B, et al. Diagnostic value of routine chest radiography in febrile, neutropenic children for early detection of pneumonia and mould infections. Support Care Cancer. 2012;20(10):2589-94. PubMed PMID: 22278307. Epub 2012/01/27. eng.

46. Stokes DC, Shenep JL, Parham D, Bozeman PM, Marienchek W, Mackert PW. Role of flexible bronchoscopy in the diagnosis of pulmonary infiltrates in pediatric patients with cancer. J Pediatr. 1989;115(4):561-7.

47. Girmenia C, Martino P. Pulmonary infections complicating hematological disorders. Semin Respir Crit Care Med. 2005;26(5):445-57. PubMed PMID: 16267697. Epub 2005/11/04. eng.

48. Nucci M, Nouér SA, Anaissie E. Distinguishing the causes of pulmonary infiltrates in patients with acute leukemia. Clin Lymphoma Myeloma Leuk. 2015;15:S98-S103.

49. Jenney ME, Faragher EB, Jones PHM, Woodcock A. Lung function and exercise capacity in survivors of childhood leukaemia. Med Pediatr Oncol. 1995;24(4):222-30.

50. Ek T, Mellander L, Andersson B, Abrahamsson J. Immune reconstitution after childhood acute lymphoblastic leukemia is most severely affected in the high risk group. Pediatr Blood Cancer. 2005;44(5):461-8.

51. Charpidou AG, Gkiozos I, Tsimpoukis S, Apostolaki D, Dilana KD, Karapanagiotou EM, et al. Therapy-induced toxicity of the lungs: an overview. Anticancer Res. 2009;29(2):631-9. PubMed PMID: 19331213. Epub 2009/04/01. eng.

52. Vahid B, Marik PE. Pulmonary complications of novel antineoplastic agents for solid tumors. Chest. 2008;133(2):528-38.

53. Andre N, Meille C. Taxanes in paediatric oncology: and now? Cancer Treat Rev. 2006;32(2):65-73. PubMed PMID: 16497442. Epub 2006/02/25. eng.

54. Latiff ZA, Kamal NA, Jahendran J, Alias H, Goh BS, Zakaria SZS, et al. Vincristineinduced vocal cord palsy: case report and review of the literature. J Pediatr Hematol Oncol. 2010;32(5):407-10.

55. Dhakal S, Weiner D, Schwartz C, Constine LS. Pulmonary effects of antineoplastic therapy. In: Schwartz C, Hobbie W, Constine L, Ruccione K, editors. Survivors of childhood and adolescent cancer. Cham: Springer; 2015. p. 201-27.

56. Matsuno O. Drug-induced interstitial lung disease: mechanisms and best diagnostic approaches. Respir Res. 2012;13(1):39. PubMed PMID: PMC3426467.

57. Borzone G, Moreno R, Urrea R, Meneses M, OyarzÚN M, Lisboa C. Bleomycin-induced chronic lung damage does not resemble human idiopathic pulmonary fibrosis. Am J Respir Crit Care Med. 2001;163(7):1648-53.

58. Huang T-T, Hudson MM, Stokes DC, Krasin MJ, Spunt SL, Ness KK. Pulmonary Outcomes in Survivors of Childhood Cancer: A Systematic Review. Chest. 2011;140(4):881-901. PubMed PMID: PMC3904488.

59. Mertens AC, Yasui Y, Liu Y, Stovall M, Hutchinson R, Ginsberg J, et al. Pulmonary complications in survivors of childhood and adolescent cancer. Cancer. 2002;95(11):2431-41.

60. McDonald S, Rubin P, Phillips TL, Marks LB. Injury to the lung from cancer therapy: clinical syndromes, measurable endpoints, and potential scoring systems. Int J Radiat Oncol Biol Phys. 1995;31(5):1187-203. PubMed PMID: 7713782. Epub 1995/03/30. eng.

61. Sleijfer S. Bleomycin-induced pneumonitis. Chest. 2001;120(2):617-24.

62. Mucci GA, Torno LR. Handbook of long term care of the childhood cancer survivor. Boston: Springer; 2015. 
63. Azambuja E, Fleck JF, Batista RG, Menna Barreto SS. Bleomycin lung toxicity: who are the patients with increased risk? Pulm Pharmacol Ther. 2005;18(5):363-6. PubMed PMID: 15939315. Epub 2005/06/09. eng.

64. Tantawy AAG, Elbarbary N, Ahmed A, Mohamed NA, Ezz-Elarab S. Pulmonary complications in survivors of childhood hematological malignancies: single-center experience. Pediatr Hematol Oncol. 2011;28(5):403-17.

65. De A, Guryev I, LaRiviere A, Kato R, Wee CP, Mascarenhas L, et al. Pulmonary function abnormalities in childhood cancer survivors treated with bleomycin. Pediatr Blood Cancer. 2014;61(9):1679-84.

66. Kaplan E, Sklar C, Wilmott R, Michaels S, Ghavimi F. Pulmonary function in children treated for rhabdomyosarcoma. Med Pediatr Oncol. 1996;27(2):79-84. PubMed PMID: 8649324. Epub 1996/08/01. eng.

67. White DA, Stover DE. Severe bleomycin-induced pneumonitis. Clinical features and response to corticosteroids. Chest. 1984;86(5):723-8.

68. Chen J, Stubbe J. Bleomycins: towards better therapeutics. Nat Rev Cancer. 2005;5(2):10212. PubMed PMID: 15685195. Epub 2005/02/03. eng.

69. Hagimoto N, Kuwano K, Nomoto Y, Kunitake R, Hara N. Apoptosis and expression of Fas/ Fas ligand mRNA in bleomycin-induced pulmonary fibrosis in mice. Am J Respir Cell Mol Biol. 1997;16(1):91-101.

70. Eigen H, Wyszomierski D. Bleomycin lung injury in children: Pathophysiology and guidelines for management. J Pediatr Hematol Oncol. 1985;7(1):71-8.

71. Cooper JA Jr, White DA, Matthay RA. Drug-induced pulmonary disease. Part 1: cytotoxic drugs. Am Rev Respir Dis. 1986;133(2):321-40. PubMed PMID: 3511808. Epub 1986/02/01. eng.

72. Ohnuma T, Holland JF, Masuda H, Waligunda JA, Goldberg GA. Microbiological assay of bleomycin: inactivation, tissue distribution, and clearance. Cancer. 1974;33(5):1230-8.

73. Lazo JS, Merrill WW, Pham, Lynch TJ, McCallister J, Ingbar D. Bleomycin hydrolase activity in pulmonary cells. J Pharmacol Exp Ther. 1984;231(3):583-8.

74. Sausville EA, Peisach J, Horwitz SB. Effect of chelating agents and metal ions on the degradation of DNA by bleomycin. Biochemistry. 1978;17(14):2740-6.

75. Ortiz LA, Lasky J, Hamilton RF Jr, Holian A, Hoyle GW, Banks W, et al. Expression of TNF and the necessity of TNF receptors in bleomycin-induced lung injury in mice. Exp Lung Res. 1998;24(6):721-43. PubMed PMID: 9839161. Epub 1998/12/05. eng.

76. Weiss RB, Muggia FM. Cytotoxic drug-induced pulmonary disease: update 1980. Am J Med. 1980;68(2):259-66. PubMed PMID: 6153504. Epub 1980/02/01. eng.

77. Limper AH. Chemotherapy-induced lung disease. Clin Chest Med. 2004;25(1):53-64. PubMed Epub 2004/04/06. eng.

78. Oakhill A, Green I, Knowlson G, Cameron A, Shah K, Hill F, et al. Busulphan lung in childhood. J Clin Pathol. 1981;34(5):495-500.

79. Pearl M. Busulfan lung. Am J Dis Child. 1977;131(6):650-2.

80. Abid SH, Malhotra V, Perry MC. Radiation-induced and chemotherapy-induced pulmonary injury. Curr Opin Oncol. 2001;13(4):242-8. PubMed PMID: 11429481. Epub 2001/06/29. eng.

81. Kayton ML. Pulmonary metastasectomy in pediatric patients. Thorac Surg Clin. 2006;16(2):167-83.

82. Fuchs J, Seitz G, Handgretinger R, Schäfer J, Warmann SW. Surgical treatment of lung metastases in patients with embryonal pediatric solid tumors: an update. Semin Pediatr Surg. 2012;21(1):79-87.

83. Meyers RL, Katzenstein HM, Krailo M, McGahren ED, Malogolowkin MH. Surgical resection of pulmonary metastatic lesions in children with hepatoblastoma. J Pediatr Surg. 2007;42(12):2050-6.

84. McBride JT, Wohl MEB, Strieder DJ, Jackson AC, Morton JR, Zwerdling RG, et al. Lung growth and airway function after lobectomy in infancy for congenital lobar emphysema. J Clin Investig. 1980;66(5):962. 
85. Spurbeck WW, Davidoff AM, Lobe TE, Rao BN, Schropp KP, Shochat SJ. Minimally invasive surgery in pediatric cancer patients. Ann Surg Oncol. 2004;11(3):340-3. PubMed PMID: 14993031. Epub 2004/03/03. eng.

86. Harting MT, Blakely ML, Jaffe N, Cox CS Jr, Hayes-Jordan A, Benjamin RS, et al. Longterm survival after aggressive resection of pulmonary metastases among children and adolescents with osteosarcoma. J Pediatr Surg. 2006;41(1):194-9.

87. Laros C, Westermann C. Dilatation, compensatory growth, or both after pneumonectomy during childhood and adolescence. A thirty-year follow-up study. J Thorac Cardiovasc Surg. 1987;93(4):570-6.

88. Kreisel D, Krupnick AS, Huddleston CB. Outcomes and late complications after pulmonary resections in the pediatric population. Semin Thorac Cardiovasc Surg. 2004;16(3):215-9.

89. Abel RM, Brown J, Moreland B, Parikh D. Pulmonary metastasectomy for pediatric solid tumors. Pediatr Surg Int. 2004;20(8):630-2. PubMed PMID: 15258816. Epub 2004/07/20. eng.

90. Werner H, Pirie G, Nadel H, Fleisher A, LeBlanc J. Lung volumes, mechanics, and perfusion after pulmonary resection in infancy. J Thorac Cardiovasc Surg. 1993;105(4):737-42.

91. Parisi MT, Fahmy JL, Kaminsky CK, Malogolowkin MH. Complications of cancer therapy in children: a radiologist's guide. Radiographics. 1999;19(2):283-97.

92. Cournard A, Himmelstein A, et al. A follow-up study of the cardiopulmonary function in four young individuals after pneumonectomy. J Thorac Surg. 1947;16(1):30-49. PubMed PMID: 20286102. Epub 1947/02/01. eng.

93. Powell RW, Luck SR, Raffensperger JG. Pneumonectomy in infants and children: the use of a prosthesis to prevent mediastinal shift and its complications. J Pediatr Surg. 1979;14(3):231-7.

94. Westfelt JN, Nordwall A. Thoracotomy and scoliosis. Spine. 1991;16(9):1124-5.

95. Uderzo C, Marraro G, Riva A, Bonanomi E, Vaj P, Marchi P, et al. Pulmonary thromboembolism in leukaemic children undergoing bone marrow transplantation. Bone Marrow Transplant. 1993;11(3):201-3.

96. Lee EY, Kritsaneepaiboon S, Arellano CMR, Grace RF, Zurakowski D, Boiselle PM. Unsuspected pulmonary emboli in pediatric oncology patients: detection with MDCT. Am J Roentgenol. 2010;194(5):1216-22.

97. Marraro G, Uderzo C, Masera G, Marchi P, Castagnini G, Vaj PL. Acute respiratory failure and pulmonary thrombosis in leukemic children. Cancer. 1991;67(3):696-702.

98. Andrew M, David M, Adams M, Ali K, Anderson R, Barnard D, et al. Venous thromboembolic complications (VTE) in children: first analyses of the Canadian Registry of VTE. Blood. 1994;83(5):1251-7.

99. Brandao LR, Kletzel M, Boulad F, Kurtzberg J, Maloney K, Fligman I, et al. A prospective longitudinal multicenter study of coagulation in pediatric patients undergoing allogeneic stem cell transplantation. Pediatr Blood Cancer. 2008;50(6):1240-6.

100. Nowak-Göttl U, Kenet G, Mitchell LG. Thrombosis in childhood acute lymphoblastic leukaemia: epidemiology, aetiology, diagnosis, prevention and treatment. Best Pract Res Clin Haematol. 2009;22(1):103-14.

101. Versluys AB, Bresters D. Pulmonary complications of childhood cancer treatment. Paediatr Respir Rev. 2015;17:63-70.

102. Thurlbeck WM. Postnatal growth and development of the lung 1. Am Rev Respir Dis. 1975;111(6):803-44.

103. Narayanan M, Owers-Bradley J, Beardsmore CS, Mada M, Ball I, Garipov R, et al. Alveolarization continues during childhood and adolescence: new evidence from helium-3 magnetic resonance. Am J Respir Crit Care Med. 2012;185(2):186-91.

104. Thomas ED, Lochte HL Jr, Cannon JH, Sahler OD, Ferrebee JW. Supralethal whole body irradiation and isologous marrow transplantation in man. J Clin Invest. 1959;38:1709-16.

105. Australasian Bone Marrow Transplant Recipient Registry. Australasian Bone Marrow Transplant Recipient Registry: Annual Data Summary 2014. Darlinghurst: ABMTRR; 2015.

106. Tomblyn M, Chiller T, Einsele H, Gress R, Sepkowitz K, Storek J, et al. Guidelines for preventing infectious complications among hematopoietic cell transplantation recipients: a global perspective. Biol Blood Marrow Transplant. 2009;15(10):1143-238. 
107. Quigg TC, Kim Y-J, Goebel WS, Haut PR. Lung function before and after pediatric allogeneic hematopoietic stem cell transplantion: a predictive role for DLCO/VA. J Pediatr Hematol Oncol. 2012;34(304-309):304.

108. Bruno B, Souillet G, Bertrand Y, Werck-Gallois MC, So Satta A, Bellon G. Effects of allogeneic bone marrow transplantation on pulmonary function in 80 children in a single paediatric centre. Bone Marrow Transplant. 2004;34(2):143-7. PubMed PMID: 15170172.

109. Gower WA, Collaco JM, Mogayzel PJ Jr. Lung function and late pulmonary complications among survivors of hematopoietic stem cell transplantation during childhood. Paediatr Respir Rev. 2011;11:115-22.

110. Inaba H, Yang J, Pan J, Stokes DC, Krasin MJ, Srinivasan A, et al. Pulmonary dysfunction in survivors of childhood hematologic malignancies after allogeneic hematopoietic stem cell transplantation. Cancer. 2010;116(8):2020-30.

111. Cooke KR, Yanik GA. Lung injury following hematopoietic cell transplantation. In: Forman SJ, Negrin RS, Antin JH, Appelbaum FR, editors. Thomas' hematopoietic cell transplantation. Chichester: Wiley-Blackwell; 2009. p. 1456-72.

112. Michelson PH, Goyal R, Kurland G. Pulmonary complications of haematopoietic cell transplantation in children. Paediatr Respir Rev. 2007;8:46-61.

113. Khurshid I, Anderson LC. Non-infectious pulmonary complications after bone marrow transplantation. Postgrad Med J. 2002;78:257-62.

114. Panoskaltsis-Mortari A, Griese M, Madtes DK, Belperio JA, Haddad IY, Folz RJ, et al. An official American Thoracic Society research statement: noninfectious lung injury after hematopoietic stem cell transplantation: idiopathic pneumonia syndrome. Am J Respir Crit Care Med. 2011;183(9):1262-79. PubMed PMID: 21531955.

115. Coomes SM, Hubbard LLN, Moore BB. Impaired pulmonary immunity post-bone marrow transplant. Immunol Res. 2011;50(1):78-86. PubMed PMID: PMC3310400.

116. Soubani AO, Pandya CM. The spectrum of noninfectious pulmonary complications following hematopoietic stem cell transplantation. Hematol Oncol Stem Cell Ther. 2010;3(3):143-57.

117. Collin BA, Leather HI, Wingard JR, Ramphal R. Evolution, incidence, and susceptibility of bacterial bloodstream isolates from 519 bone marrow transplant patients. Clin Infect Dis. 2001;33(7):947-53.

118. Stiff P. Mucositis associated with stem cell transplantation: current status and innovative approaches to management. Bone Marrow Transplant. 2001;27(Suppl 2):S3-11.

119. Sano H, Kobayashi R, Iguchi A, Suzuki D, Kishimoto K, Yasuda K, et al. Risk factor analysis of idiopathic pneumonia syndrome after allogeneic hematopoietic SCT in children. Bone Marrow Transplant. 2014;49(1):38-41.

120. Sakaguchi H, Takahashi Y, Watanabe N, Doisaki S, Muramatsu H, Hama A, et al. Incidence, clinical features, and risk factors of idiopathic pneumonia syndrome following hematopoietic stem cell transplantation in children. Pediatr Blood Cancer. 2012;58(5):780-4.

121. Gorak E, Geller N, Srinivasan R, Espinoza-Delgado I, Donohue T, Barrett AJ, et al. Engraftment syndrome after nonmyeloablative allogeneic hematopoietic stem cell transplantation: incidence and effects on survival. Biol Blood Marrow Transplant. 2005;11:542-50.

122. Kambham N, Higgins JP, Sundram U, Troxell ML. Hematopoietic stem cell transplantation: graft versus host disease and pathology of gastrointestinal tract, liver, and lung. Adv Anat Pathol. 2014;21(5):301-20.

123. Jagasia MH, Greinix HT, Arora M, Williams KM, Wolff D, Cowen EW, et al. National Institutes of Health Consensus Development Project on Criteria for Clinical Trials in Chronic Graft-versus-Host Disease: I. The 2014 Diagnosis and Staging Working Group Report. Biol Blood Marrow Transplant. 2015;21:389-401.

124. Shulman HM, Cardona DM, Greenson JK, Hingorani S, Horn T, Huber E, et al. NIH Consensus Development Project on Criteria for Clinical Trials in Chronic Graft-versus-Host Disease: II. The 2014 Pathology Working Group Report. Biol Blood Marrow Transplant. 2015;21:589-603.

125. Haddad IY. Stem cell transplantation and lung dysfunction. Curr Opin Pediatr. 2013;25(3):350-6.

126. Epler GR. Diagnosis and treatment of constrictive bronchiolitis. Med Rep. 2010;2:32. PubMed PMID: PMC2948389. 
127. Flowers ME, Martin PJ. How we treat chronic graft-versus-host disease. Blood. 2015;125(4):606-15.

128. Holbro A, Lehmann T, Girsberger S, Stern M, Gambazzi F, Lardinois D, et al. Lung histology predicts outcome of bronchiolitis obliterans syndrome after hematopoietic stem cell transplantation. Am Soc Blood Marrow Transplant. 2013;19:973-80.

129. Barker AF, Bergeron A, Rom WN, Hertz MI. Obliterative bronchiolitis. N Engl J Med. 2014;370:1829-8.

130. Bhatia S, Ramsay NK, Steinbuch M, Dusenbery KE, Shapiro RS, Weisdorf DJ, et al. Malignant neoplasms following bone marrow transplantation. Blood. 1996;87:3633-9.

131. Curtis RE, Travis LB, Rowlings PA, Socie G, Kingma DW, Banks PM, et al. Risk of lymphoproliferative disorders after bone marrow transplantation: a multi-institutional study. Blood. 1999;94(7):2208-16.

132. Jagadeesh D, Woda BA, Draper J, Evens AM. Post transplant lymphoproliferative disorders: risk, classification, and therapeutic recommendations. Curr Treat Options Oncol. 2012;13(1):122-36. PubMed PMID: 22241590.

133. Catani L, Gugliotta L, Vianelli N, Nocentini F, Baravelli S, Bandini G, et al. Endothelium and bone marrow transplantation. Bone Marrow Transplant. 1996;17(2):277-80.

134. Bunte MC, Patnaik MM, Pritzker MR, Burns LJ. Pulmonary veno-occlusive disease following hematopoietic stem cell transplantation: a rare model of endothelial dysfunction. Bone Marrow Transplant. 2008;41(8):677-86.

135. Cines DB, Pollak ES, Buck CA, Loscalzo J, Zimmerman GA, McEver RP, et al. Endothelial cells in physiology and in the pathophysiology of vascular disorders. Blood. 1998;91(10):3527-61.

136. Dandoy CE, Hirsch R, Chima R, Davies SM, Jodele S. Pulmonary hypertension after hematopoietic stem cell transplantation. Bone Marrow Transplant. 2013;19(11):1546-56.

137. Rabinovitch M. Molecular pathogenesis of pulmonary aterial hypertension. J Clin Invest. 2012;122:4306-13.

138. Jodele S, Hirsch R, Laskin B, Davies S, Witte D, Chima R. Pulmonary arterial hypertension in pediatric patients with hematopoietic stem cell transplant-associated thrombotic microangiopathy. Am Soc Blood Marrow Transplant. 2013;19:202-7.

139. Steward CG, Pellier I, Mahajan A, Ashworth MT, Stuart AG, Fasth A, et al. Severe pulmonary hypertension: a frequent complication of stem cell transplantation for malignant infantile osteopetrosis. Br J Haematol. 2004;124(1):63-71.

140. Rosenzweig E, Barst R. Pulmonary arterial hypertension in children: A medical update. Curr Opin Pediatr. 2008;20:288-93.

141. Frazier AA, Franks TJ, Mohammed TL, Ozbudak IH, Galvin JR. From the Archives of the AFIP: pulmonary veno-occlusive disease and pulmonary capillary hemangiomatosis. Radiographics. 2007;27(3):867-82.

142. Mandel J, Mark EJ, Hales CA. Pulmonary veno-occlusive disease. Am J Respir Crit Care Med. 2000;162(5):1964-73.

143. Holcomb BW Jr, Loyd JE, Ely EW, Johnson J, Robbins IM. Pulmonary veno-occlusive disease: a case series and new observations. Chest. 2000;118(6):1671-9.

144. Almagro P, Alvarez M, Garau J. Lung biopsy in pulmonary veno-occlusive disease. Chest. 2001;120(4):1421-2.

145. Izbicki G, Shitrit D, Schechtman I, Bendayan D, Fink G, Sahar G, et al. Recurrence of pulmonary veno-occlusive disease after heart-lung transplantation. Lung biopsy in pulmonary veno-occlusive disease. J Heart Lung Transplant. 2005;24(5):635-7.

146. Serota FT, August CS, Koch PA, Fox W, D'Angio GJ. Pulmonary function in patients undergoing bone marrow transplantation. Med Pediatr Oncol. 1984;12(2):137-43. PubMed PMID: 6366504.

147. Uderzo C, Rovelli A, Meloni G, Balduzzi A, Pezzini C, Colombini A, et al. Evaluation of late side-effects after bone marrow transplantation in children with leukemia. Bone Marrow Transplant. 1991;8(Suppl 1):44-6. PubMed PMID: 1760638. 
148. Kaplan EB, Wodell RA, Wilmott RW, Leifer B, Lesser ML, August CS. Late effects of bone marrow transplantation on pulmonary function in children. Bone Marrow Transplant. 1994;14(4):613-21. PubMed PMID: 7858537.

149. Cerveri I, Fulgoni P, Giorgiani G, Zoia MC, Beccaria M, Tinelli C, et al. Lung function abnormalities after bone marrow transplantation in children: has the trend recently changed? Chest. 2001;120(6):1900-6. PubMed PMID: 11742920.

150. Nenadov Beck M, Meresse V, Hartmann O, Gaultier C. Long-term pulmonary sequelae after autologous bone marrow transplantation in children without total body irradiation. Bone Marrow Transplant. 1995;16(6):771-5. PubMed PMID: 8750268.

151. Kaya Z, Weiner DJ, Yilmaz D, Rowan J, Goyal RK. Lung function, pulmonary complications, and mortality after allogeneic blood and marrow transplantation in children. [Erratum appears in Biol Blood Marrow Transplant. 2009 Sep;15(9):1141]. Biol Blood Marrow Transplant. 2009;15(7):817-26. PubMed PMID: 19539213.

152. Fulgoni P, Zoia MC, Corsico A, Beccaria M, Georgiani G, Bossi G, et al. Lung function in survivors of childhood acute lymphoblastic leukemia. Chest. 1999;116(5):1163-7. PubMed PMID: 10559071.

153. Yen KT, Lee AS, Krowka MJ, Burger CD. Pulmonary complications in bone marrow transplantation: a practical approach to diagnosis and treatment. Clin Chest Med. 2004;25(1):189-201.

154. Pulsipher MA, Skinner R, McDonald GB, Hingorani S, Armenian SH, Cooke KR, et al. National Cancer Institute, National Heart, Lung and Blood Institute/Pediatric Blood and Marrow Transplantation Consortium First International Consensus Conference on late effects after pediatric hematopoietic cell transplantation: the need for pediatric-specific long-term follow-up guidelines. Am Soc Blood Marrow Transplant. 2012;18:334-47.

155. Uhlving HH, Mathiesen S, Buchvald F, Green K, Heilmann CJ, Gustafsson PM, et al. Small airways dysfunction in long term survivors of pediatric stem cell transplantation. Pediatr Pulmonol. 2014;50(7):704-12.

156. Lahzami S, Schoefel RE, Pechey V, Greenwood M, Salome CM, Berend N, et al. Small airways function declines after allogeneic haematopoietic stem cell transplantation. Eur Respir J. 2011;38(5):1180-8.

157. Australian Institute of Health and Welfare. Cancer in Australia: an overview 2014. Cancer series no 90 Cat no CAN 88 Canberra, AIHW2014.

158. Krowka MJ, Rosenow rEC, Hoagland HC. Pulmonary complications of bone marrow transplantation. Chest. 1985;87(2):237-46.

159. Mulder RL, Thönissen NM, van der Pal HJ, Bresser P, Hanselaar W, Koning CC, et al. Pulmonary function impairment measured by pulmonary function tests in long-term survivors of childhood cancer. Thorax. 2011;66(12):1065-71.

160. Doll DC, Ringenberg QS, Yarbro J. Vascular toxicity associated with antineoplastic agents. J Clin Oncol. 1986;4(9):1405-17. 